\title{
A Quality Function Deployment (QFD) Approach in Determining the Employer's Selection Criteria
}

\author{
Nora Muda and Noor Sulawati Mat Roji \\ School of Mathematical Sciences, Faculty of Science \& Technology, Universiti Kebangsaan Malaysia, 43600 Bangi, Selangor, Malaysia \\ Correspondence should be addressed to Nora Muda; noramuda@ukm.edu.my
}

Received 23 March 2015; Revised 13 August 2015; Accepted 19 August 2015

Academic Editor: Eleonora Bottani

Copyright ( 2015 N. Muda and N. S. Mat Roji. This is an open access article distributed under the Creative Commons Attribution License, which permits unrestricted use, distribution, and reproduction in any medium, provided the original work is properly cited.

The industrial training program is part of the academic curriculum at the tertiary level. It plays an important role in providing students with the exposure to a real working environment in the industry. Through this program, the higher education institutions (HEI) could identify the gaps in the curriculum based on the requirements from the industry. In addition, the feedback from the industry will help the HEI to equip students with relevant skills according to the demands from the industry. Indirectly, it can help to address the issue of unemployed graduates of which the number seems to increase from time to time. Therefore, this study aims to obtain the feedback from the employers out there in order to determine the most preferred criteria in selecting students for the industrial training placement by using Quality Function Deployment (QFD) approach. The findings, through the development of house of quality based on the QFD approach, show that communication skills and students' participation in sports and cocurricular activities at their university are the most preferred selection criteria. Therefore, the QFD approach can be used to translate the employers' feedback in improving the marketability of the students in the industry.

\section{Introduction}

Human capital is an important asset in the process of developing a country. Countries with high-skilled human capital are able to generate economic activities to a more dynamic par with developed countries like the United States or Japan. Therefore, various approaches have been initiated, especially in the higher education system, in order to produce human capital with high skills and competency by requiring students to undergo the industrial training program before being awarded with certificates, diplomas, or degrees.

The industrial training program exposes students to the real working environment and enables them to apply the theoretical and practical knowledge that they have learned by performing the tasks assigned by their current organization [1]. The industrial training program is also the best mechanism for the HEI to evaluate the effectiveness of their programs or courses that they have been offering to the students. In addition, the program also helps the university to foster a good relationship with various organizations in the industry. The relationship is beneficial to both parties in an effort to develop and produce a first class human capital which is highly required by the country.

The Universiti Kebangsaan Malaysia (UKM) is one of the higher education institutions providing opportunities for their students to be exposed to the real work situations. Various courses and programs have been taught in the university as to improve students' skills and knowledge and applying during their works or during their industrial training. However, the requirements and expectations of the industry are constantly changing as the Malaysia's economics and industries keep changing. Therefore, it is an obligation to the university to assess the ability of their students, whether they meet the demands of the industry, and what criteria and skills that the industry needs from UKM graduate students. For that reason, the feedback from the employers regarding the selection of students to join their organization is very important to assist the university in preparing and providing a better service in the future.

In an effort to improve and enhance the quality of service of School of Mathematical Sciences (PPSM), Faculty of Science and Technology, UKM, in preparing graduates 
who are skilled and competent to the industry, the survey was conducted to get feedbacks from employers to assess the effectiveness of the courses offered and the skills acquired by PPSM students. Thus, with the approach of Quality Function Deployment (QFD) analysis, the absolute weights for technical requirement (outcomes of the program) based on the development of house of quality from the employer's perspective were studied and investigated for identifying the program learning outcomes (HPP) and program outcomes (OP) which need to be emphasized or improvement in meeting current industry needs. This allows the PPSM, FST, and UKM to improve the existing programs so that graduates are more competitive and more marketable, thereby reducing the number of graduates who are unemployed.

For the final year students of PPSM, FST of session 2010/2011, the industrial training program is a compulsory since it was stopped and was not compulsory to the students on last 1995 session. Therefore, the feedback from the industries and the students is needed and important as to find out the effect of the IT on the students. The most important is to find out the marketability of the PPSM students to be hired by the industries after the IT program. There were various studies on the industrial training that have been done in some higher institutions, namely, by Goi and Lau [2], Ng et al. [3], Abdul-Karim [4], Shahrir et al. [5], Omar et al. [6], Lai et al. [7], and Awang [8].

Human capital that has been equipped with skills such as communication skills, ability to work in teams, ability to think creatively, and ability to make decisions and has both good leadership skills and academic excellence will be more competitive in the industry. According to Madar et al. [9], the ability of employees to handle highly skilled tasks will benefit the company by improving the quality of production and becoming more competitive in local and international markets. Moreover, Rasul et al. [10] found that employers are more in favour of employees with basic, critical thinking, resource, and interpersonal skills as well as being knowledgeable in systems and technologies and qualified personnel in improving the marketability in the industry. Therefore, this study was conducted by using the Quality Function Deployment (QFD) approach to determine the selection criteria of industrial training students at the agencies and, thus, giving a first-hand overview to the university in dealing with the demand from the industry in future.

In this study, the feedback from the employers and the students who undergo the IT is needed to determine the effectiveness and the marketability of the PPSM student in getting a job. This investigation on the IT program is important and will be beneficial to the PPSM as it will enhance the effectiveness of the IT program and beneficial to the students as it will increase the marketability of the students in finding the jobs as it was conducted during the final year after students have completed all the units needed before finishing their study and graduated, compared to before which was on the second year of study.

\section{Literature Review}

The concept of Quality Function Deployment (QFD) has been introduced by Akao and Katsuyo in 1966 at Matsushita
Electric. The QFD can be used in various sectors such as services, automotive, hospitality, and manufacturing. Nevertheless, the first application was in the manufacturing sector by Toyota. Having proven its effectiveness by Toyota, the quality practitioners have expanded the use of QFD in the service sector [11-19]. Therefore, Mazur [15] defines the QFD as an approach to satisfy the customers (Quality) by translating their needs into the design and ensuring all the organizational units (Function) are working together to identify the design features systematically to have more detailed information that can be disclosed and controlled (Deployment). The QFD is a method of developing a design quality which aims to satisfy the customers by translating their demands and designs for a certain product or service [20]. The QFD can also be used in education sector by assisting the HEI to form the subjects or topics of specific courses for each subject and restructure the university curriculum. For example, Mazur [15] and Gonzalez et al. [21] have applied the concept of QFD in forming the subject of Total Quality Management (TQM) and International Business based on the feedback from the students, university staff, and employers in the industry.

Kauffmann et al. [22] have applied QFD to develop decision model to prioritized course contents based on degree of impact on program objectives. The model was developed to quantify curricular decisions involved in restructuring a Masters of Engineering Management degree program. Based on QFD model, it provides a practical and quantitative methodology for developing faculty consensus in the selection of curricular topics based on a strategic program focus. While Singh et al. [23] used QFD to revamp existing industrial engineering curriculum by reassessing it with outcomebased accreditation, based on output from roof matrix in the house of quality, they identified the overlapping and prerequisite relations among courses. Therefore, they can remove any overlapping courses and identify newly required courses. Aytaç and Deniz [24] have applied QFD method to review curriculum of the Tyre Technology Department at the Kocaeli University Kosekoy Vocational School of Higher Education (KU-KVSHE), Turkey. They have conducted direct interview with the stakeholder of local tyre companies in Turkey and get the feedback regarding the expectation from the stakeholder on the graduates and the curriculum. The interview was also conducted by the lecturer of that department so that they can get feedback from both sides, stakeholders and the school management, and finally proposed new module of IT program which includes the industry demand, preparing the students which are skilled as per employers' demand.

Quinn et al. [25] studied identifying and evaluating techniques that were used to improve the quality in higher education. They examined customer and measured customer quality perceptions to identify the differences and similarities surrounding quality improvement efforts in each of three service areas that were typically found in higher education: academic, administrative, and auxiliary functions. While Singh et al. [23] evaluate the quality of educational institute based on five identified groups of "dimensions of quality" and twelve sets of "enablers" in an educational institute, then, they outline a QFD model based on interrelationship and 
intrarelationship among the dimensions of quality, enablers, and customers. Finally, the indices that they developed are then utilized for quality planning and monitoring in educational institute. Qureshi et al. [26] also studied the quality of Higher Educational Institute in Pakistan where, from the QFD model, they highlighted the major concerned areas of quality improvements in teaching and also highlighted some benchmarks where other institutions are more productive. All the studies reported using QFD to restructure and enhance the curriculum for their university program in line with the current industry demand.

The QFD approach also requires the development of house of quality in integrating customers' feedback for the technical requirements of the organization and analyzing problems or enhancements that should be given priority in improving the quality of their services. Akao et al. [27] define employers as an external client to the university. Feedbacks from employers are beneficial to the university in helping them to evaluate the effectiveness of the university programs or courses offered. In addition, this feedback can be used to enhance the students' skills in line with the needs of employers and, thus, reduce the unemployment rate among the graduates.

\section{Materials and Methods}

A survey has been conducted on the industries which are involved in the student's industrial training program of PPSM students to investigate the marketability of the PPSM students. The questionnaires that can be referred to in the Appendix were distributed to the employers during the assessment visit by the PPSM supervisor. The survey on the employers involved 136 respondents of which 29 were from government sectors, 77 were from private sectors, 27 were from government agencies, and 3 from other sectors. There were 5 parts in the employer questionnaires to be answered. In order to determine the feedback from the employers regarding their selection of students who undergo industrial training at their agencies, Likert's scale ranging from 1 to 5 was also used to measure. The scale range of 1 represents very unimportant while 5 represents very important. A descriptive analysis was done to look at respondents' profiles based on demographic factors while the hypothesis testing was done to compare the criteria of selection of industrial training students. The hypothesis that was tested is as follows:

$H_{0}$ : there is no difference between criteria of selection of industrial training students from the employers feedback.

The analysis of variance (ANOVA) was used to get the conclusions on the hypothesis stated above.

3.1. Quality Function Deployment for Employer's Criteria of Selection. In this section, we propose an assessment of PPSM student's skill based on the program and courses that they have taken during their studies in PPSM, FST, and UKM via QFD methodology. The voice of employers in agencies was taken as their feedback on how they select the PPSM students to join their agencies to undergo industrial training.

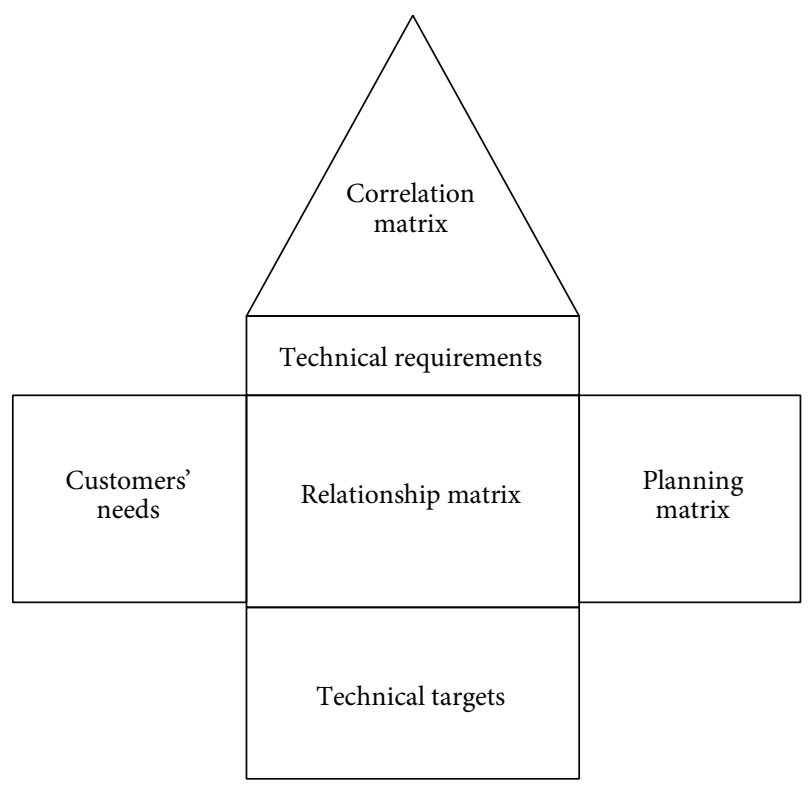

FIGURE 1: House of quality.

3.2. House of Quality. The QFD approach requires the development of house of quality in connecting the customers' voice with the specified products or services, technical requirements, process of planning control, and manufacturing operations [28]. In this study, the customer's voice is the voice of employers of the agencies that PPSM students undergo their industrial training. There are six steps in building a house of quality, namely, the customers' needs, technical requirements, relationship matrix, planning matrix, correlation matrix, and technical targets (see Figure 1).

Therefore, in this study, the employers are the external customers of the School of Mathematical Sciences (PPSM). The employers' feedback of satisfaction on student's skills and abilities is categorized according to the domain: the affective domain, psychomotor domain, cognitive domain, and psychomotor and cognitive domain, based on course learning outcomes of STQS3886 (Industrial Training course) by referring to Malaysian Qualification Agency as guidelines to good practices in assessment to students in HEI as shown in Table 1.

In addition, the technical requirements describe the model of "how" the organization responds to "what" the customer needs for a certain product or service. The selection criteria of industrial training students are the technical requirements which describe the criteria required by employers in selecting students to undergo the training at their organizations based on the previous research.

The relationship matrix $\left(R_{i j}\right)$ is the "heart" of the QFD [29]. The purpose of this communication matrix is to indicate whether the technical requirements are fulfilled. This matrix connects the employee response to the selection criteria of student by using a specific symbol that reflects the degree of relationship. The planning matrix is part of the house of quality as a marketing strategy and planning decision. The QFD team will choose some important information such as 
TABLE 1: Employers' feedback on the satisfaction level of student skills.

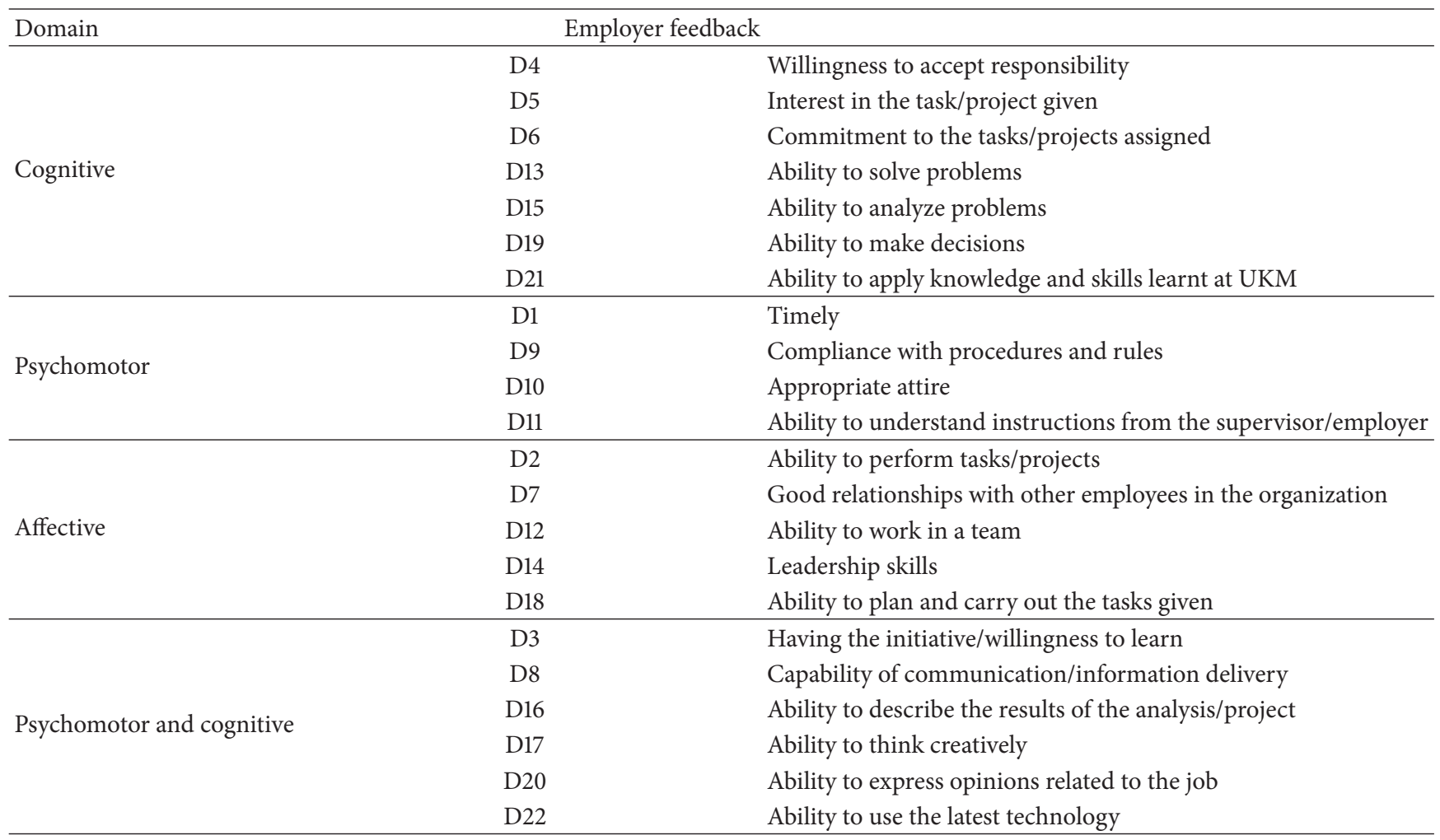

the important requirement for the employee $(s)$, which is a scale of 1-5, performance of the employee's voice $(t)$, target of employee's voice $(u)$, and ratio of improvement $(v)$, where

$$
t_{i}=\frac{b_{i}}{c}
$$

in which $b=\left(\sum_{i}\right.$ number of employer at value $\left.i\right) \times i$.

$c$ is a total number of employees:

$$
v_{i}=\frac{u_{i}}{t_{i}}
$$

$u=$ target and $t=$ performance of employers' feedback.

Besides that, the point of services/sales $(w)$ and the absolute weight of student's voice $(z)$ were also considered in the house of quality, where

$$
z_{i}=s_{i} \times v_{i} \times w_{i} .
$$

The correlation matrix is a correlation or "roof" of the house of quality. This "roof" can be seen in Figure 1 as correlation matrix at the top of the figure. This roof shows the relationship of each indicator of criteria of selection by employee. This relationship is used to determine whether the indicators support or hinder each other. The technical target is the last matrix in the house of quality. It is determined as an absolute weight of selection criteria indicator $(x)$ and calculated by

$$
x=\sum R_{i j} S_{i} ; \quad i=1,2, \ldots, n ; j=1,2, \ldots, k,
$$

where $n$ is the number of employee's voices and $k$ is the number of indicators of all criteria of selection, $x$ is an absolute weight, $R_{i j}$ is a relationship matrix, and $S_{i}$ is a "degree of importance" to customer with value ranges from 3 to 5 .

Normally, information found in the technical target is our priority and benchmark for criteria of selection. Therefore, the indicator of the criteria of selection which has a high absolute weight value should be given a priority in the process of maintaining the services and meeting the employees' needs.

\section{Results and Discussion}

Based on the survey conducted, there were 149 respondents among the students, of which $45.6 \%$ were from Statistics program, $44.3 \%$ were from Mathematics program, and $10.1 \%$ were from Actuarial Science program. Among them, 24.2\% were males and $71.1 \%$ were females. In terms of organizational sectors which provided a workplace to the students, there were $26.8 \%$ from financial sector, followed by $18.8 \%$ from service sector, and $11.4 \%$ were from other sectors as stated in Table 4. On the other hand, there were 136 respondents among the employers of which $56.6 \%$ were from private sectors followed by $21.3 \%$ from government sectors and $19.9 \%$ were from government agencies; only $2.2 \%$ were from other sectors. There were a total of 134 employers that provided feedback on the satisfaction level of students' skills as well as the criteria of selection of industrial trainings' students. There are four types of organization involved in the study: $21 \%$ from government, $57 \%$ from private, $20 \%$ 
TABLE 2: Profiles of respondents.

\begin{tabular}{lcc}
\hline Profiles of employers & Number & $\%$ \\
\hline Type of organization & & \\
Government & 29 & 21.3 \\
Private & 77 & 56.6 \\
Government agency & 27 & 19.9 \\
Others & 3 & 2.2 \\
Organization sectors & & \\
Finance & 37 & 27.2 \\
Manufacturing & 13 & 9.6 \\
Services & 24 & 17.6 \\
Industry & 4 & 2.9 \\
Property development and construction & 2 & 1.5 \\
Education & 14 & 10.3 \\
Consultation & 5 & 3.7 \\
Transportation & 1 & 0.7 \\
Agriculture and food & 1 & 0.7 \\
Defence and security & 1 & 0.7 \\
Communication and IT & 8 & 5.9 \\
Others & 25 & 18.4 \\
\hline
\end{tabular}

from government agencies such as MARA, Felda, and 2\% from other organizations. The 12 criteria that were asked are communication skills, languages (English, Malay, and other languages), working experience, IT duration, academic qualification, the impressive resume, company policy, quota of IT, and students involvement in cocurriculum and sports.

Employers who provided their feedback as shown in Table 2 are the field supervisors from various sectors such as finance, manufacturing, services, industry, real estate development and construction, education, consulting, transportation, agriculture and food, defence, and security as well as communication and IT. They were asked to give a scale of whether the twelve items of criteria of selection are important or not ranging from 1 to 5 . Based on the twelve items of criteria of selection, the mean for each item from the scale of 5 is calculated. We found that the highest mean value according to the criteria of selection is the criteria of communication skills ( 4.5 from scale 5 ), followed by the criteria of mastery in English and Malay languages (4.29 and 4.13), the criteria of academic qualification (4.07), and the criteria of company policy (4.02). From the feedback of employers regarding the criteria of selection, the findings show that the overall mean is 3.76 from scale 5.0. It has been shown that the employers could say that all criteria of selection that have been asked are more likely important to them in selecting the students to undergo industrial training at their agencies.

Then, analysis of variance (ANOVA) was conducted to test whether there are significant differences between the criteria of selection. Any criteria which give a $p$ value less than 0.05 are considered significant. From the ANOVA, there are significant differences according to the criteria of selection in the communication skills, mastery in English and Malay languages, and the duration of industrial training as shown in Table 3. Therefore, the analysis is extended by developing the house of quality in order to obtain the most preferred selection criteria by employers in selecting students to undergo the industrial training at their organization.

The relationships between the employers' satisfaction level on student skills and each selection criteria were categorized by specific symbols depending on correlation and while the relationships in the "roof" of house of quality were determined also based on the correlation. The planning matrix values were produced by (1) to (3), while the level of difficulty and targets for each of the criteria were set by the PPSM. However, (4) has been used to obtain absolute values for each criterion. A combination of all information would then form a house of quality as shown in Figure 2.

From the development of house of quality, the most preferred selection criteria by employers can be determined based on the high absolute weight value as in the technical target of house of quality. However, the high absolute weight value that should be given priority cannot be determined by its value, because the absolute weight value depends on the scale that has been used in obtaining feedback from the employers and the scale of the relationship in the relationship matrix.

The greater the interval is, the higher the scale will be used in absolute weight value for the technical requirements. Therefore, this study uses a scale of 1-5 in which 1 represents "very dissatisfied" and 5 represents "very satisfied" for the preferred criteria being used. To evaluate the relationship in the relationship matrix, the scale of 0,3 , and 9 was used in which the scale of 9 refers to significant at 0.01 level, 3 refers to significant at 0.05 level, and 0 refers to not significant.

Based on the findings from the house of quality as shown in Figure 2, the list of preferred selection criteria by the employers are illustrated in Table 4. From Table 4, we can conclude that the five most preferred criteria by employers in selecting the students to undergo the industrial training at their organizations are communication skills, students' participation in sports and cocurricular activities, working experience, and mastery in English language. All the 5 highest absolute weight values have relationship with academic qualification. Therefore, the students' academic qualification also indirectly became one of the most preferred selection criteria for company to select student to undergo industrial training in their organization. The participation of students in sports and cocurricular activities has been proven by many previous studies such as Ahmad et al. [30] and Suhana and Ahmad [31] which explains that both activities provide a good impact on enhancing job's skills such as leadership, communication, decision making, competing, interaction with peers, and thinking creatively. These criteria give an early impression that employers require students to have good job employability skills in order to be more competitive in the industry besides being academically excellent.

Based on the results obtained, the School of Mathematical Sciences, UKM, would also have a role in providing their students with skills and criteria as required by the industries. The courses offered should include the skills needed by students such as communication skills. Students should be exposed to a variety of tasks or skills that enable students to practice their communication skills, for example, through presentations of 
TABLE 3: ANOVA results for employers' selection criteria of industrial training students.

\begin{tabular}{|c|c|c|c|c|}
\hline \multicolumn{2}{|c|}{ Employer's selection criteria of students' LI } & \multirow{2}{*}{$\frac{\text { Mean }}{4.5}$} & \multirow{2}{*}{$\begin{array}{c}F \text {-value } \\
5.54\end{array}$} & \multirow{2}{*}{$\frac{p \text {-value }}{0.00^{*}}$} \\
\hline B4 & Communication skills & & & \\
\hline B2 & Mastery in English language & 4.29 & 3.98 & $0.01^{*}$ \\
\hline B1 & Mastery in Malay language & 4.13 & 20.81 & $0^{*}$ \\
\hline B7 & Academic qualifications & 4.07 & 2.15 & 0.09 \\
\hline B9 & Company/organization policy & 4.02 & 0.63 & 0.59 \\
\hline B8 & A convincing resume & 3.95 & 0.98 & 0.40 \\
\hline B6 & Duration of LI & 3.82 & 2.83 & $0.04^{*}$ \\
\hline $\mathrm{B} 10$ & Amount of students' intake for LI for a particular period & 3.73 & 0.47 & 0.71 \\
\hline B11 & Students' involvement in extracurricular activities in university & 3.51 & 1.64 & 0.18 \\
\hline B12 & Students' involvement in sport activities & 3.22 & 2.22 & 0.09 \\
\hline B3 & Ability to master other languages & 3.02 & 1.63 & 0.19 \\
\hline B5 & Working experience & 2.88 & 0.38 & 0.77 \\
\hline
\end{tabular}

( ${ }^{*}$ significant as $p$ value less than 0.05$)$.

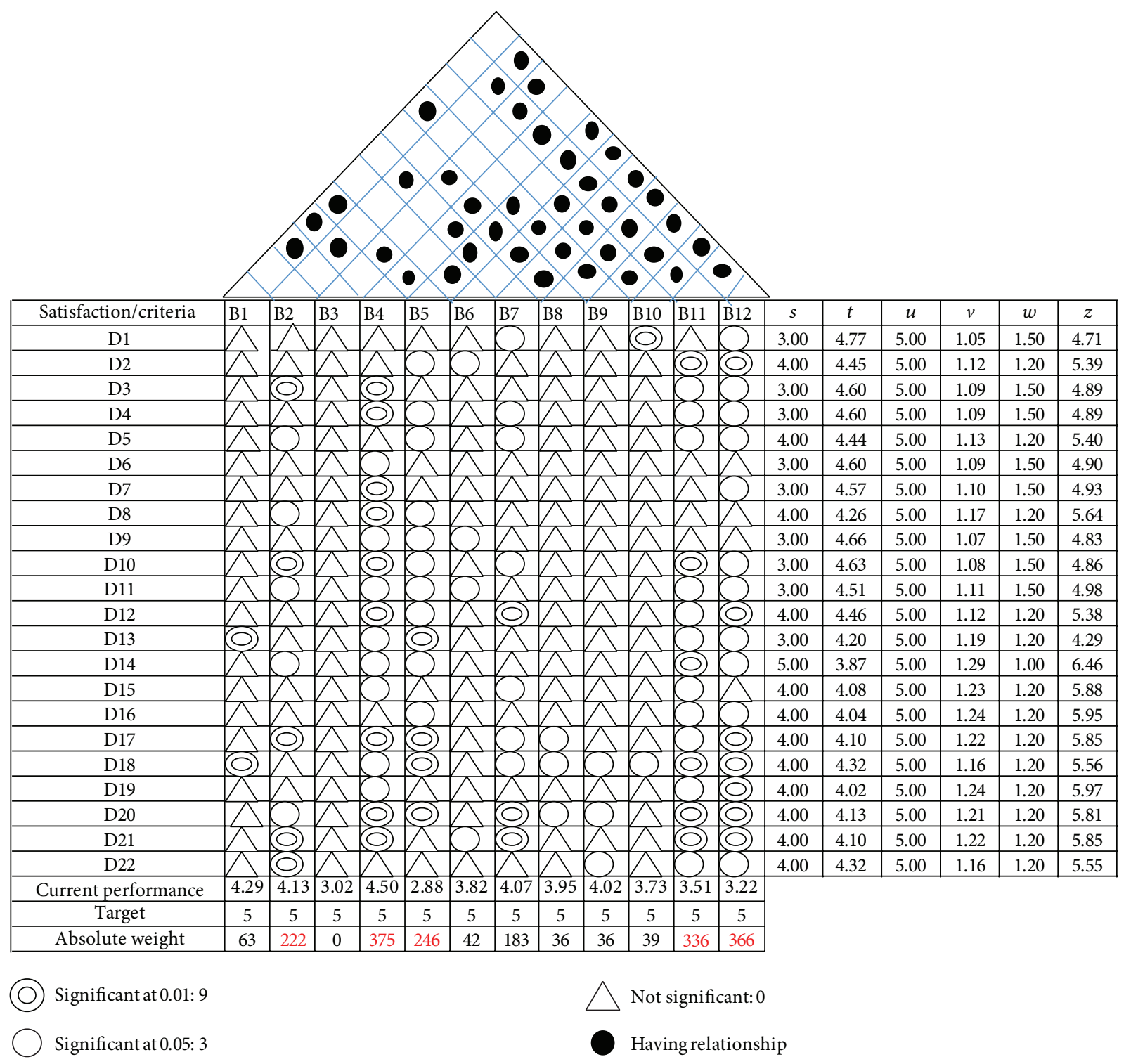

FIGURE 2: House of quality of employers' selection criteria. 
TABLE 4: Criteria that should be given priority.

\begin{tabular}{ll}
\hline & Preferred selection criteria \\
\hline B4 & Communication skills \\
B12 & Participation in sports activities \\
B11 & Participation cocurricular activities \\
B5 & Working experience \\
B2 & Mastery in English language \\
\hline
\end{tabular}

student assignment, visits to industry for an interview, which directly emphasizes and strengths their English language. Besides that, encouraging students to actively participate in cocurricular activities and sports is a must. All the necessary criteria should also be taken into account by the university in order to prepare all their graduates that can fulfill the industries demand.

This QFD method which was applied in this study assessed the customer satisfaction, the industries (customer) on the UKM students performance during their industrial training. The criteria of selection that we get are the voice of customer (employers) that should be translated by the UKM to produce graduates that have skills as what industries demand. This is important to enhance the marketability of the UKM students.

\section{Conclusion}

This study has applied QFD approach in translating the employer's voice in the industrial training program through the formation of house of quality. The program is used to evaluate the effectiveness of the programs or courses offered by the university. Thus, through the formation of the house of quality, the most preferred selection criteria from the house of quality enable PPSM to identify the necessary skills that students should have in order for employers to select them to undergo industrial training at their organizations. The most preferred criteria by employers are communication skills, students' participation in sports and cocurricular activities, working experience, mastery in English language, and academic qualification. Therefore, a thorough and systematic planning should be done by PPSM to ensure that these skills are developed and integrated into the curriculum of teaching and learning.

The findings of this study may indirectly improve the existing courses in UKM by ensuring that the courses offered can provide students with good communication skills and enhance the English language skills among students. In addition, they will enhance the interests of the students to participate more in extracurricular activities and sports at the university. The feedbacks from the industry are their voice that needs UKM students, PPSM students to have criteria that they need to become their employees. These findings are really useful as it will help university to prepare their students with skills needed by the industries and increase the marketability of the UKM students in finding job after graduation.

\section{Appendix}

\section{A. Questionnaires}

\section{A.1. Part A: Employer's Background Information}

(A1) Organization name:

(A2) Organization address:

(A3) Size of organization:

$\square$ Less than 50 employees

$\square$ 51-150 employees

$\square$ More than 150 employees

(A4) Organization is a:

$\square$ Head office

$\square$ Branch

$\square$ Not applicable

(A5) Organization's type:

$\square$ Government

$\square$ Private

$\square$ Government agency

$\square$ Others. Please state

(A6) Organization's sector:
$\square$ Financial
$\square$ Manufacturing
$\square$ Services
$\square$ Industrial
$\square$ Property and development
$\square$ Education
$\square$ Consultation
$\square$ Transportation
$\square$ Food and agriculture
$\square$ Security and defense
$\square$ IT and communication
$\square$ Others. Please state:

(A7) How many students per intake for industrial training purposes for a particular period in your organization?

\section{A.2. Part B: Student's Selection Criteria for Industrial Training. See Table 5.}

A.3. Part C: Tasks Delegation to Industrial Training Students. See Table 6.

A.4. Part D: Satisfaction Level on Students' Skills and Ability. See Table 7 . 
TABLE 5

\begin{tabular}{|c|c|c|c|c|c|c|}
\hline Number & Item & & & cal & & \\
\hline $\mathrm{B} 1$ & English proficiency & 1 & 2 & 3 & 4 & 5 \\
\hline B2 & Malay proficiency & 1 & 2 & 3 & 4 & 5 \\
\hline B3 & Proficiency in other languages & 1 & 2 & 3 & 4 & 5 \\
\hline B4 & Communication skills & 1 & 2 & 3 & 4 & 5 \\
\hline B5 & Working experience & 1 & 2 & 3 & 4 & 5 \\
\hline B6 & Duration of industrial training & 1 & 2 & 3 & 4 & 5 \\
\hline B7 & Academic qualifications & 1 & 2 & 3 & 4 & 5 \\
\hline B8 & Impressive resume & 1 & 2 & 3 & 4 & 5 \\
\hline B9 & Company/organisation policy & 1 & 2 & 3 & 4 & 5 \\
\hline $\mathrm{B} 10$ & Amount of students' intake for industrial training for a particular period & 1 & 2 & 3 & 4 & 5 \\
\hline B11 & Students' involvement in extracurricular activities in university & 1 & 2 & 3 & 4 & 5 \\
\hline B12 & Students' involvement in sport activities & 1 & 2 & 3 & 4 & 5 \\
\hline
\end{tabular}

Circle your answer based on the scale given.

$1=$ very unimportant, 2 = unimportant, $3=$ not sure, $4=$ important, and $5=$ very important.

TABLE 6

\begin{tabular}{llllcc}
\hline Number & Item & & Scale & \\
\hline C1 & Tasks given are suitable for the students' academic background & 1 & 2 & 3 & 4 \\
C2 & Students are exposed to the real working environment & 1 & 2 & 3 & 4 \\
C3 & Students are exposed to the organization's work ethics & 1 & 2 & 3 & 4 \\
\hline
\end{tabular}

Circle your answer based on the scale given.

1 = strongly disagree, 2 = disagree, $3=$ not sure, 4 = agree, and $5=$ strongly agree.

TABLE 7

\begin{tabular}{|c|c|c|c|c|c|c|}
\hline Number & Item & & & Scal & & \\
\hline D1 & Punctuality & 1 & 2 & 3 & 4 & 5 \\
\hline $\mathrm{D} 2$ & Ability to perform task/project & 1 & 2 & 3 & 4 & 5 \\
\hline D3 & Initiative/willingness to learn & 1 & 2 & 3 & 4 & 5 \\
\hline $\mathrm{D} 4$ & Willingness to accept responsibility & 1 & 2 & 3 & 4 & 5 \\
\hline D5 & Interest towards task/project given & 1 & 2 & 3 & 4 & 5 \\
\hline D6 & Commitment towards task/project given & 1 & 2 & 3 & 4 & 5 \\
\hline D7 & Good relationship with other personnel in your organization & 1 & 2 & 3 & 4 & 5 \\
\hline D8 & Ability to communicate/convey information & 1 & 2 & 3 & 4 & 5 \\
\hline D9 & Follow rules and regulation & 1 & 2 & 3 & 4 & 5 \\
\hline $\mathrm{D} 10$ & Properly dressed and neat & 1 & 2 & 3 & 4 & 5 \\
\hline D11 & Ability to understand instruction from supervisor/employer & 1 & 2 & 3 & 4 & 5 \\
\hline D12 & Ability to work in group & 1 & 2 & 3 & 4 & 5 \\
\hline D13 & Ability to solve problems & 1 & 2 & 3 & 4 & 5 \\
\hline D14 & Ability to lead & 1 & 2 & 3 & 4 & 5 \\
\hline D15 & Ability to analyse problems & 1 & 2 & 3 & 4 & 5 \\
\hline D16 & Ability to interpret analysis/project result & 1 & 2 & 3 & 4 & 5 \\
\hline D17 & Ability to think creatively & 1 & 2 & 3 & 4 & 5 \\
\hline D18 & Ability to plan and execute task given & 1 & 2 & 3 & 4 & 5 \\
\hline D19 & Ability to make decision & 1 & 2 & 3 & 4 & 5 \\
\hline D20 & Ability to give opinion related to the task & 1 & 2 & 3 & 4 & 5 \\
\hline $\mathrm{D} 21$ & Ability to apply knowledge and skills learned in UKM & 1 & 2 & 3 & 4 & 5 \\
\hline D22 & Ability to use the latest technologies & 1 & 2 & 3 & 4 & 5 \\
\hline
\end{tabular}

Circle your answer based on the scale given.

$1=$ very unsatisfied, $2=$ unsatisfied, $3=$ not sure, $4=$ satisfied, and $5=$ very satisfied. 
A.5. Part E: Additional Information. Would you be interested in offering the student a permanent position?

\section{Conflict of Interests}

The authors declare that there is no conflict of interests regarding the publication of this paper.

\section{Acknowledgment}

The authors would like to thank UKM for providing the research grant (UKM-PTS-2012-069 \& UKM-PTS-2011039).

\section{References}

[1] L. K. Chiu, N. I. Mahat, S. Hassan, A. R. Chik, and M. A. Yahya, "The evaluation of student performance and program management practicum in Universiti Utara Malaysia," Malaysian Journal of Learning \& Instruction, vol. 7, pp. 133-164, 2010.

[2] C. L. Goi and C. S. H. Lau, "Graduates' employment: the value of Curtin University of Technology Sarawak's graduates," International Journal of Marketing Studies, vol. 2, no. 1, pp. 127-132, 2010.

[3] P. Y. Ng, S. K. Abdullah, P. H. Nee, and N. H. Tiew, "Employers' feedback on business graduates: an exploratory study in Curtin Sarawak," International Review of Business Research Papers, vol. 5, no. 4, pp. 306-321, 2009.

[4] Z. A. Abdul-Karim, "Measuring the success of industrial internship programme for undergraduate study," in Proceedings of the International Engineering Education Conference, pp. 143-147, Medina, Saudi Arabia, 2009.

[5] A. Shahrir, W. B. Wan Hamidon, A. O. K. R. Riza Atiq et al., "Maklum Balas Penyelia Latihan Industri Terhadap Objektif Dan Hasil Pembelajaran," in Seminar Pengajaran dan Pembelajaran Berkesan 2005, pp. 164-172, 2005.

[6] M. Z. Omar, Z. M. Darus, N. T. Kofli, K. Mat, S. A. Osman, and M. N. A. Rahman, "Manafaat kursus latihan industri dalam Meningkatkan keyakinan pelajar," Peka, vol. 2008, pp. 1-13, 2008.

[7] F. W. Lai, Z. A. Abd-Karim, and S. K. Johl, "Examining a successful industrial training program model: inter-relationship among the three main stakeholders: students, university and host companies," in Proceedings of the 2nd Regional Conference on Engineering Education (RCEE '07), pp. 24-30, December 2007.

[8] A. H. Awang, Keberkesanan kebolehpasaran pelatih dalam industri latihan vokasional terpilih di Malaysia [Ph.D. thesis], Universiti Putra Malaysia, Seri Kembangan, Malaysia, 2004.

[9] A. R. Madar, M. F. Abd Aziz, A. R. Abd Razzaq, M. Z. Mustafa, and Y. Buntat, "Kemahiran employability bagi memenuhi keperluan industri," in Seminar Kebangsaan Kemahiran Insaniah dan Kesejahteraan Sosial (SKIKS '08), pp. 385-392, 2008.

[10] M. S. Rasul, M. Y. Ismail, N. Ismail, R. Rajuddin, and R. Abd Rauf, "Aspek kemahiran 'Employability' yang dikehendaki majikan di industri pembuatan masa kini," Jurnal Pendidikan Malaysia, vol. 34, no. 2, pp. 67-79, 2009.
[11] J. W. Cadogan, A. Diamantopoulos, and C. Pahud De Mortanges, "A measure of export market orientation: scale development and cross-cultural validation," Journal of International Business Studies, vol. 30, no. 4, pp. 689-707, 1999.

[12] M. E. González, G. Quesada, and A. T. Bahill, "Improving product design using quality function deployment: the school furniture case in developing countries," Quality Engineering, vol. 16, no. 1, pp. 45-56, 2003.

[13] M. E. González, G. Quesada, R. MacK, and I. Urrutia, "Building an activity-based costing hospital model using quality function deployment and benchmarking," Benchmarking, vol. 12, no. 4, pp. 310-329, 2005.

[14] M. Jeong and H. Oh, "Quality function deployment: an extended framework for service quality and customer satisfaction in the hospitality industry," International Journal of Hospitality Management, vol. 17, no. 4, pp. 375-390, 1998.

[15] G. H. Mazur, "QFD for service industries: from voice of customer to task deployment," in Proceedings of the Fifth Symposium on Quality Function Deployment, pp. 157-162, Novi, Mich, USA, 1993.

[16] T. Peters, "Facing up to the need for a management revolution," California Management Review, vol. 30, no. 2, pp. 8-38, 1988.

[17] K. F. Pun, K. Chin, and H. Lau, "A QFD/Hoshin approach for service quality deployment: a case study," Managing Service Quality, vol. 10, no. 3, pp. 156-170, 2000.

[18] S. Y. Sohn and A. Kim, "Quality function deployment for engineering curriculum redesign," in Proceedings of the 20th Australasian Association for Engineering Education Conference (AAEE '09), pp. 343-349, December 2009.

[19] F. I. Stuart and S. S. Tax, "Planning for service quality: an integrative approach," International Journal of Service Industry Management, vol. 7, no. 4, pp. 58-77, 1996.

[20] Y. Akao, Quality Function Deployment: Integrating Customers Requirements into Product Design, translated by G. Mazur, Productivity Press, Portland, Ore, USA, 1990.

[21] M. E. Gonzalez, G. Quesada, J. Mueller, and R. D. Mueller, "International business curriculum design: identifying the voice of the customer using QFD," Journal of International Education in Business, vol. 4, no. 1, pp. 6-29, 2011.

[22] P. Kauffmann, A. Fernandez, C. Keating, D. Jacobs, and R. Unal, "Using quality function deployment to select the courses and topics that enhance program effectiveness," Journal of Engineering Education, vol. 91, no. 2, pp. 231-237, 2002.

[23] V. Singh, S. Grover, and A. Kumar, "Evaluation of quality in an educational institute: a quality function deployment approach," Educational Research and Reviews, vol. 3, no. 4, pp. 162-168, 2008.

[24] A. Aytaç and V. Deniz, "Quality function deployment in education: a curriculum review," Quality and Quantity, vol. 39, no. 4, pp. 507-514, 2005.

[25] A. Quinn, G. Lemay, P. Larsen, and D. M. Johnson, "Service quality in higher education," Total Quality Management and Business Excellence, vol. 20, no. 2, pp. 139-152, 2009.

[26] M. I. Qureshi, K. Khan, M. N. Bhatti, A. Khan, and K. Zaman, "Quality function deployment in higher education institutes of Pakistan," Middle East Journal of Scientific Research, vol. 12, no. 8, pp. 1111-1118, 2012.

[27] Y. Akao, K. Nagai, and N. Maki, "QFD concept for improving higher education," in Proceedings of the ASQC's 50th Annual Quality Congress, pp. 12-20, May 1996. 
[28] J. R. Evan and W. M. Lindsay, The Management and Control of Quality, South-Western Cengage Learning, Ontario, Canada, 8th edition, 2011.

[29] L. Cohen, Quality Function Deployment How to Make QFD Work for You, Addison-Wesley, Reading, Mass, USA, 1995.

[30] E. Ahmad, M. Y. Jailani, and K. Noraini, "Peranan Kokurikulum dalam pembangunan kemahiran generik," Jurnal Sains Sosial, vol. 2, no. 1, pp. 81-94, 2004.

[31] H. F. Suhana and J. Ahmad, "The importance of co-curriculum in education at secondary school," in Proceedings of the 4th International Conference on Teacher Education; Join Conference UPI \& UPSI, pp. 59-69, Bandung, Indonesia, November 2010. 

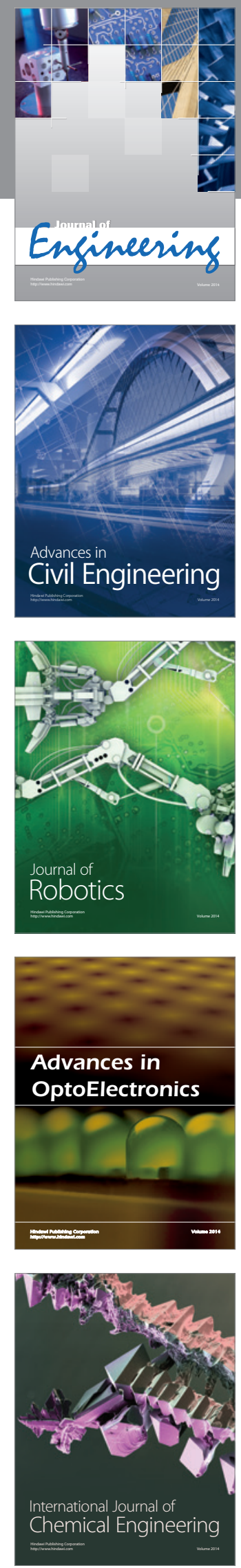

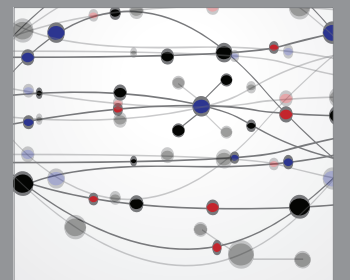

The Scientific World Journal
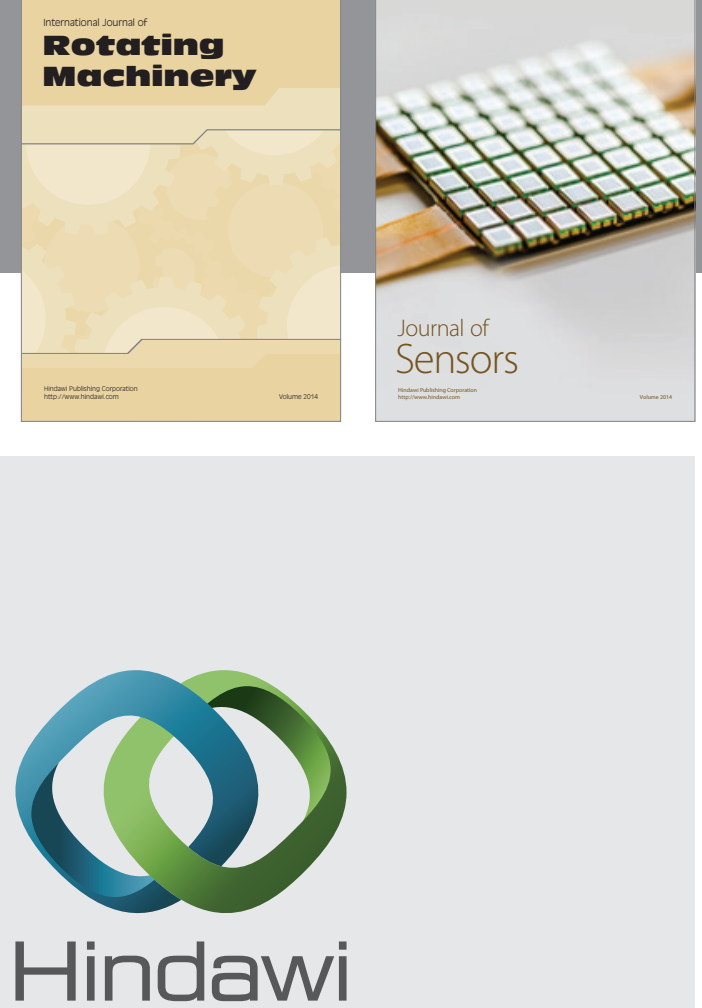

Submit your manuscripts at http://www.hindawi.com
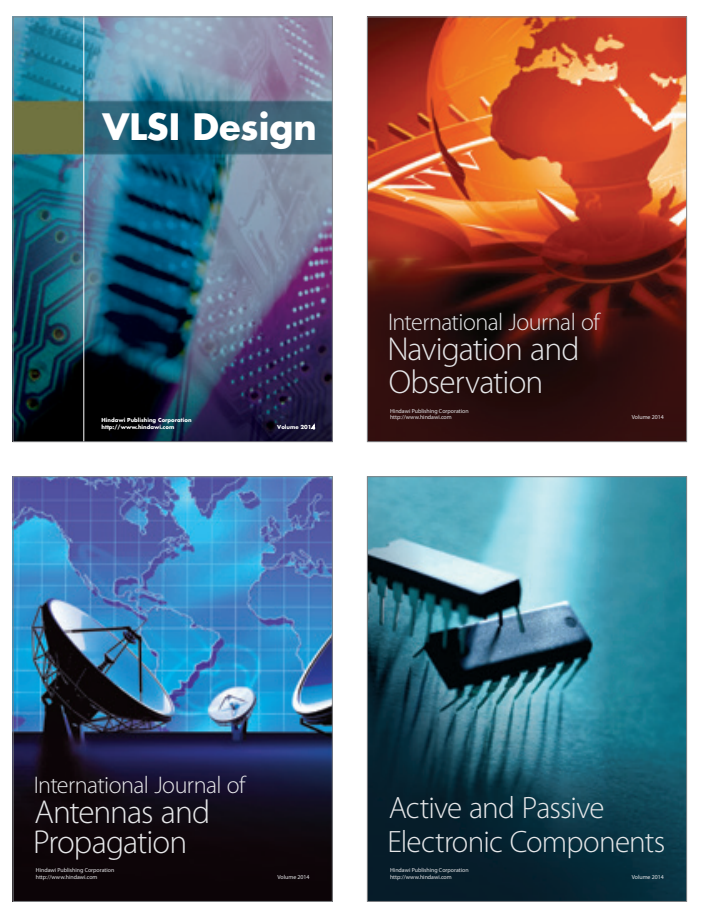
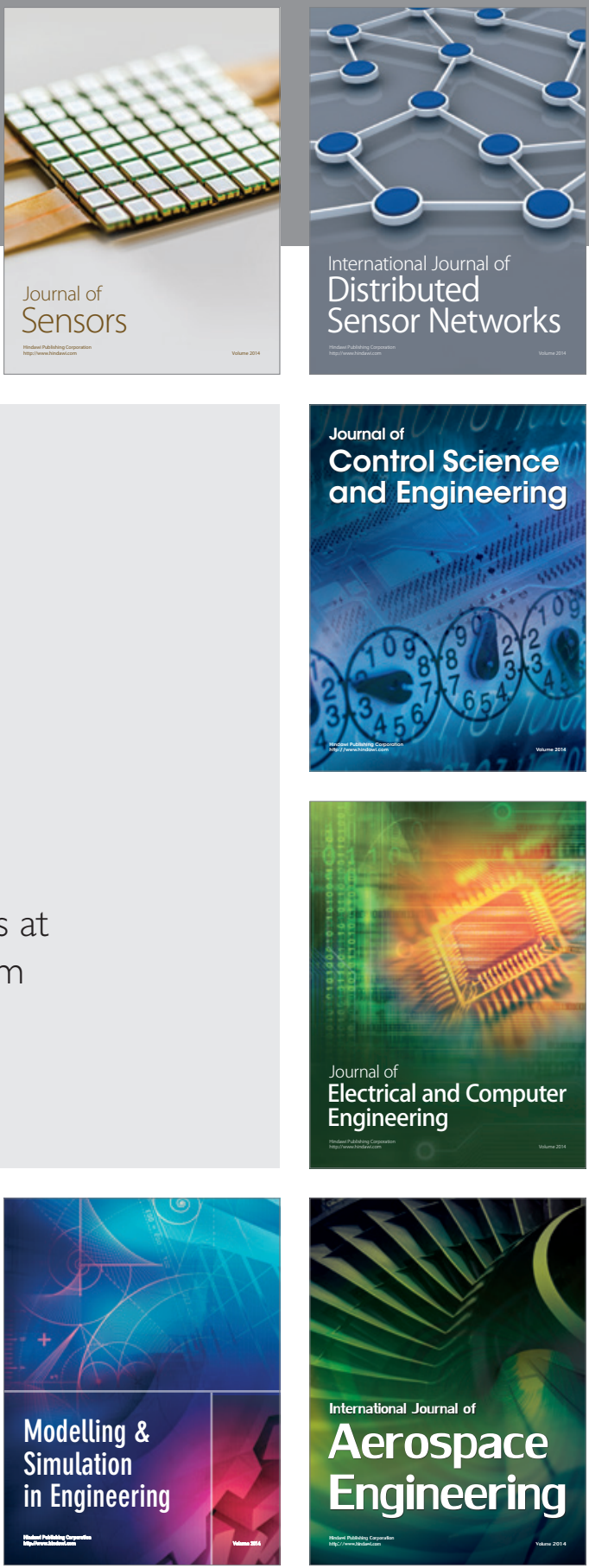

Journal of

Control Science

and Engineering
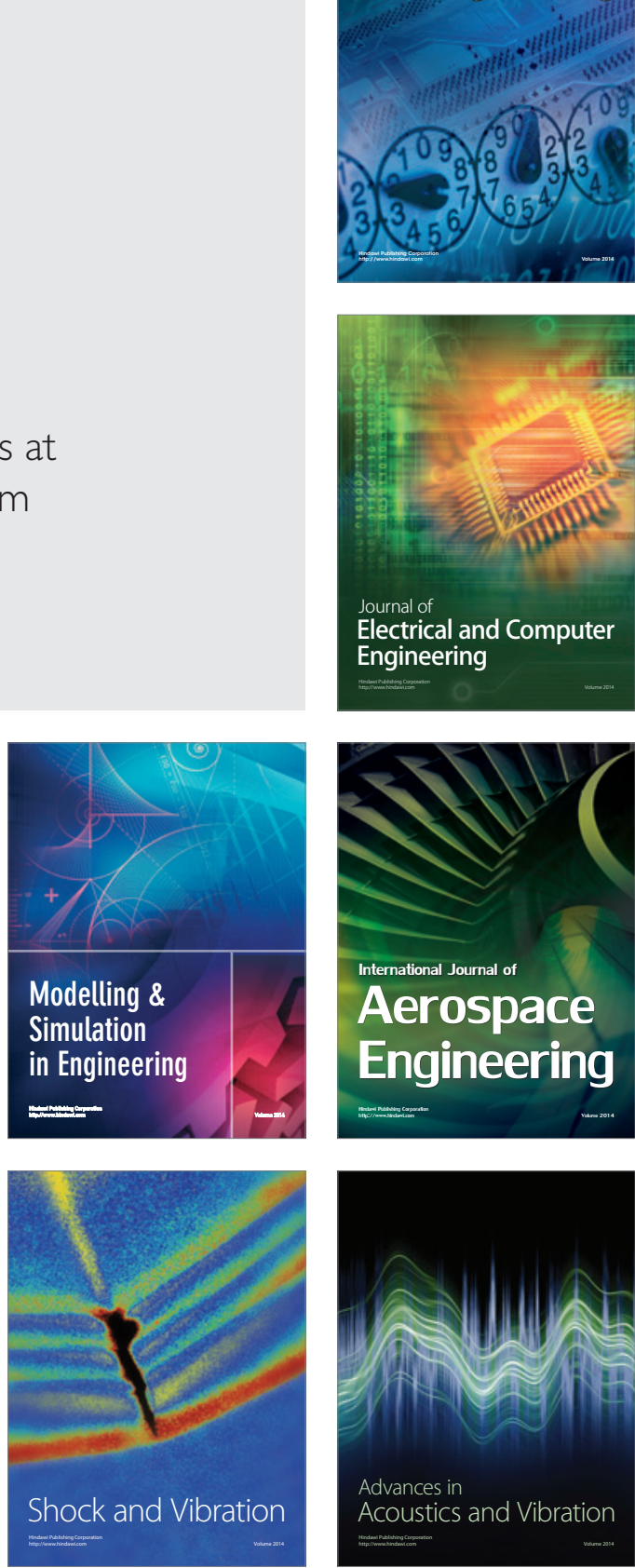